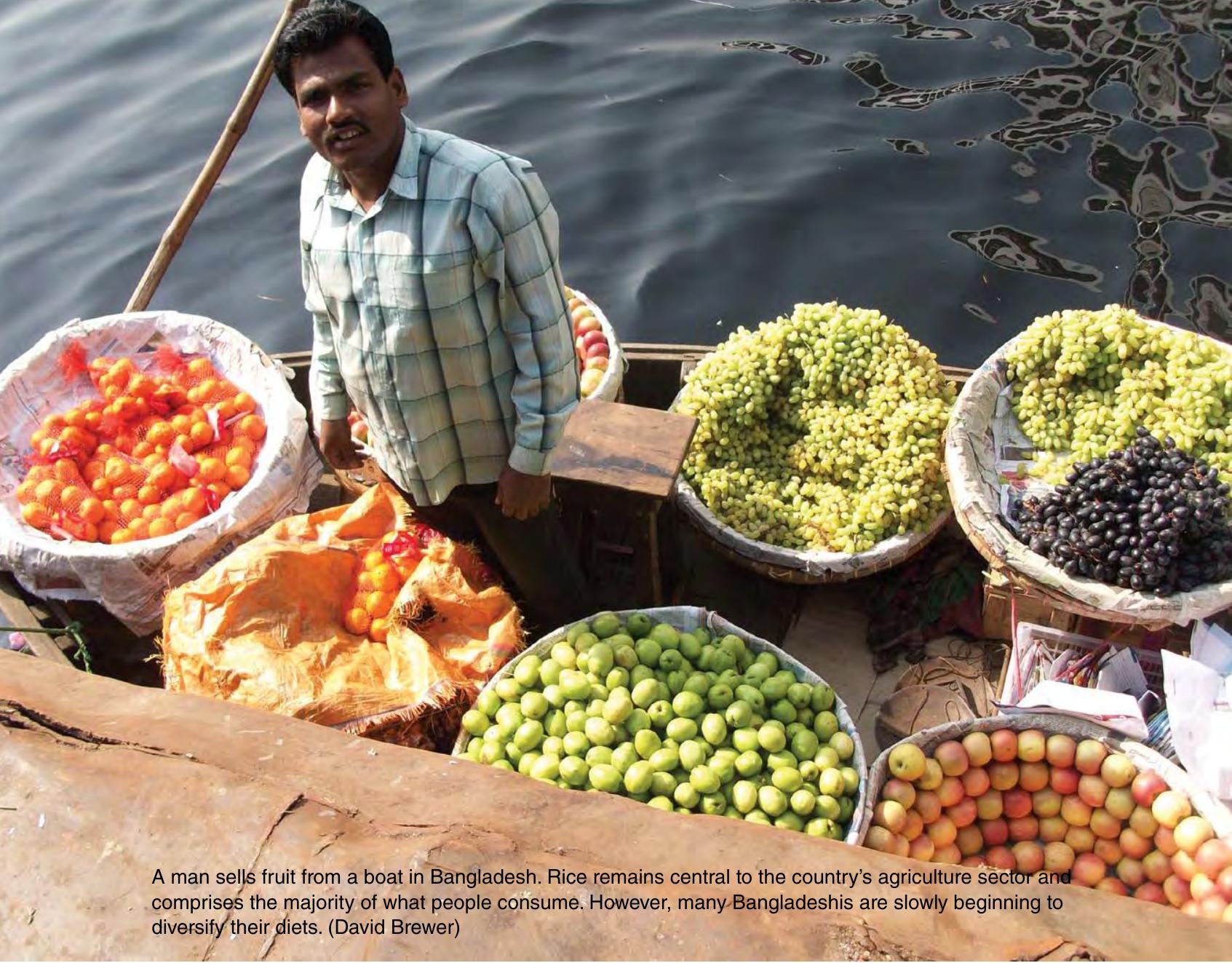

A man sells fruit from a boat in Bangladesh. Rice remains central to the country's agriculture sector an comprises the majority of what people consume. However, many-Bangladeshis are slowly beginning to diversify their diets. (David Brewer)

\title{
Diversifying Rice-centric Agriculture and Diets: the Bangladesh Experience
}

Akhter U. Ahmed* and Julie Ghostlaw

International Food Policy Research Institute (IFPRI), Dhaka, Bangladesh

* Corresponding author: a.ahmed@cgiar.org 


\section{Background}

Bangladesh has made great progress in feeding a large population with domestic agricultural production, despite facing declining arable agricultural land in an area smaller than $150,000 \mathrm{~km}^{2}$. In the early 1970s, it was a food-deficit country with a population of about 75 million. Today, with a population exceeding 160 million, the country is self-sufficient in rice production, which has tripled during the past three decades. Seed, fertilizer, and irrigation, all known as 'Green Revolution technologies', have played a major role in the growth of rice production in Bangladesh.

Bangladesh's pace of economic growth has also accelerated in recent years, with real gross domestic product (GDP) growing at a rate of $6.5 \%$ percent on average per year in 2010-2016. In the fiscal year 2016-17, GDP growth reached $7.1 \%$, the highest rate in the country's history. The incidence of poverty was also cut in half during the past 15 years, dropping from $48.9 \%$ in 2000 to $24.3 \%$ in 2016 (BBS, 2017). On the nutrition side, during the past two decades, Bangladesh recorded one of the fastest prolonged reductions in child stunting in the world - stunting dropped by 19 percentage points over 18 years, from $55 \%$ in 1997 to $36 \%$ in 2015 (NIPORT, 2015).

Despite these successes, the country faces big challenges. The Bangladeshi population suffers from sub-optimal maternal, newborn, and child health and survival outcomes. Approximately $19 \%$ of ever-married women between the ages of 15 and 49 and up to $31 \%$ of adolescent girls (15-19 years old) are undernourished (NIPORT, 2015). More than one-fourth of non-pregnant and non-lactating women are anemic, and $42-57 \%$ suffer from zinc or iodine deficiencies (ICDDRB et al., 2013). In 2015, 55\% of pregnant women were anemic (NNS, 2017).

These nutrition challenges are compounded by other downward trends. The country's pace of poverty reduction has recently stagnated. The national poverty rate fell by 1.2 percentage points annually from 2010 to 2016 compared with 1.7 from 2005 to 2010 (World Bank, 2017). The recent slowdown in agricultural growth partly explains the deceleration in poverty reduction. In 2007-2011, agricultural GDP grew at a remarkably high rate of $4.7 \%$ per annum, but during the following 5 years (2012-2016), annual growth roughly halved to $2.4 \%$. This decline is mainly due to a decreased growth rate in rice production, from $4.8 \%$ per year during 2007-2011 to only 0.7\% during 2012-2016.

This chapter reviews recent policy developments in agriculture and nutrition in Bangladesh, and then draws upon household-level data to examine trends related to agricultural production, food consumption and nutrition, and women's empowerment. Using this evidence, the authors present a government-led experiment that is working towards filling critical knowledge and action gaps for promoting nutrition-sensitive agriculture. Bringing together this evidence, they conclude that identifying, developing, and supporting synergies among the agriculture, nutrition, and health sectors is critical for Bangladesh to improve food and nutrition security.

\section{Recent Policy Developments}

Government policies and strategies have begun to underscore the importance of strengthening the linkages between agriculture and nutrition. The Country Investment Plan (CIP) for Food Security and Agricultural Development provided the foundation for improving food security, agricultural development, and nutrition in the country in 2011. Thereafter, policies began to take a more inclusive approach. For example, the 2013 National Agriculture Policy emphasized diversifying crops and producing crops with greater nutritional value to meet the nutrition demands of the population. As of March 2018, the 2013 National Agriculture Policy is undergoing stakeholder consultation, which has significant policy reform potential for strengthening the linkages between agriculture, nutrition, and gender in the country. Key recommendations for the updated National Agriculture Policy include expansion of national programs for the production of nutritious and safe foods, greater inclusion of women in the agriculture sector, strengthening agricultural value chains, and facilitating privatesector involvement.

Similarly, Bangladesh has demonstrated its strong policy commitment to improve nutrition, as evidenced by its pledge at the Nutrition for Growth Summit in 2013, its engagement in the Scaling up Nutrition (SUN) movement, its National Nutrition Policy, the proposed strengthening of 
multisectoral coordination for nutrition in its 7th Five Year Plan (2016-2020), its National Strategy for Adolescent Health (2017-2030), and its nutrition-focused health sector program (Health Nutrition and Population Sector Program (HNPSP) Project for Bangladesh).

Bangladesh is well positioned to accelerate progress on agriculture and nutrition. While progress has been made in recent years in bringing together agriculture and nutrition in policy commitments, there remains a lack of policy coordination - both within and between ministries - which undercuts effective policy implementation. Given the multisector and multistakeholder nature of food security and nutrition, formal mechanisms for inter-sectoral collaboration must be prioritized (Ahmed et al., 2011).

\section{Evidence of Linkages Among Agricultural Diversity, Dietary Diversity, and Nutritional Status}

The relationships among agricultural diversity, dietary diversity, and nutrition are complex and multidimensional. A recent study mapped five pathways through which agricultural interventions can affect nutrition, including: (i) increased food availability for household consumption; (ii) increased income for accessing food; (iii) reductions in market prices; (iv) shifts in preferences; and (v) shifts in control of resources within households (Arimond et al., 2011). Research undertaken by the International Food Policy Research Institute (IFPRI) in Bangladesh shows that Bangladeshi women are key actors within the food system, and that their empowerment improves dietary diversity as well as household food security (Sraboni et al., 2014). However, women in Bangladesh are historically less empowered and, despite playing an important role in agricultural growth, face persistent obstacles and societal and economic constraints in reaping the full benefits of agricultural livelihoods. Thus, the diminished role of women weakens the links between agriculture and nutrition in Bangladesh. Evidence from other countries in South Asia also supports the link between women's empowerment, agriculture, and dietary diversity.

There is also increasing evidence that agricultural production diversity leads to household dietary diversity. Hossain et al. (2016) found that rural households in Bangladesh that combined crop and non-crop agricultural activities (for example, crop production and livestock raising) had more diverse diets. Another study revealed that vegetable technology targeted at women who owned small land holdings increased their empowerment and improved their children's nutritional status (Hallman et al., 2003).

There is also some evidence on the relationship between dietary diversity and child nutritional status. A review of Demographic and Health Surveys (DHS) from 11 countries concluded that diverse diets are sometimes positively associated with child nutritional status (Arimond and Ruel, 2004). Studies undertaken in Bangladesh and India also found that low levels of dietary diversity are linked with poor child nutrition outcomes, such as stunting, wasting, or underweight (Rah et al., 2010; Menon et al., 2015). However, the association between dietary diversity and child nutritional status is sometimes not present or weak. This may be because minimum dietary diversity, as an indicator, is not very sensitive to changes in child nutritional status (Jones et al., 2014).

These studies contribute to an evolving understanding of the complex relationships among gender, production diversity, and nutrition outcomes. The evidence base is gradually being strengthened through research in countries including but not limited to Bangladesh. Using household survey data from Nepal, for example, Malapit et al. (2013) investigated the impact of women's empowerment in agriculture and production diversity on dietary diversity and anthropometric outcomes of mothers and children. The study showed that agricultural production diversity is positively associated with mothers' dietary diversity and body mass index, dietary diversity for children under 2 years of age and predicts weight-for-age (WAZ), weightfor-height (WHZ), and height-for-age (HAZ) z-scores of children over 2 years of age.

\section{A Rice-centric Agricultural Sector, with Implications for Nutrition}

In 2011, IFPRI researchers designed the Bangladesh Integrated Household Survey (BIHS) - the 
most comprehensive, nationally representative rural household panel survey to date in the country. IFPRI collected unique data under the BIHS, including plot-level agricultural production and practices, dietary intake of all household members using 24-hour recall, height and weight of all household members, and women's empowerment using the Women's Empowerment in Agriculture Index, a survey-based index designed to measure the empowerment, agency, and inclusion of women in the agricultural sector in an effort to identify ways to overcome those obstacles and constraints. Two panel survey rounds of the BIHS have been conducted the baseline in 2012 (BIHS, 2012) and midline in 2015 (BIHS, 2015) - which track the same set of rural households over time. Results in this section draw upon data from the BIHS and secondary data from various sources.

Today, Bangladesh's agriculture scenario still reflects the country's early thrust towards achieving rice self-sufficiency. In 2012, over onehalf $(51 \%)$ of all farmers grew only one crop: rice (Ahmed et al., 2017) (Fig. 15.1).

IFPRI research reveals that rice is one of the least profitable crops grown in Bangladesh (Ahmed et al., 2015). Why, then, do most farmers not diversify agricultural production? Yearto-year price fluctuations are much larger for non-rice crops than for rice, indicating relatively high levels of market-induced risks for production of non-rice crops. High-value crops, especially fruit and vegetables, have thin domestic markets owing to relatively low levels of demand for them due to widespread poverty and inadequate purchasing power. An increase in production causes a sharp decline in market prices.

Agricultural diversity and dietary diversity are closely linked. Nearly three-fourths of cropped land in Bangladesh is under rice cultivation, and subsequently about $71 \%$ of the total dietary energy intake comes exclusively from rice (Ahmed et al., 2017). One of the most important causes of widespread malnutrition is the deficiency in the habitual diet in Bangladesh, with rice contributing most of the total dietary energy, and other foods contributing much less than required. Although rice is a good source of calories, it is not a good source of protein and essential micronutrients. Despite this, rice provides over one-half of total protein intake (57\%), $62 \%$ of total zinc intake, and $44 \%$ of total iron intake. These statistics illustrate the dietary gaps that have largely developed as a result of Bangladesh's rice-centric agriculture sector.

Between 2012 and 2015, Bangladeshis did begin to increase their consumption of fruits, vegetables, legumes, and animal-source protein such as dairy and meat. However, the severity of dietary deficiencies is more apparent when the proportion of people who have not consumed specific food groups within the past week is analyzed (Fig. 15.2). Although the proportion of people who did not consume dairy within the past 7 days dropped from $65.2 \%$ to $47.4 \%$, one-half of rural households are still completely deficient in dairy consumption. Similarly, the proportion of people who consumed fruits and vegetables grew tremendously between 2012 and 2015, but there is still more work to be done, with $29.3 \%$ and $23.0 \%$ of rural households not consuming any fruits and legumes during the preceding 1-week period in 2015.

One alternative for getting the most nutrition out of Bangladesh's monotonous diets is to fortify highly consumed crop varieties with micronutrients through biofortification (see Chapter 5). Rice is an excellent vehicle for biofortification

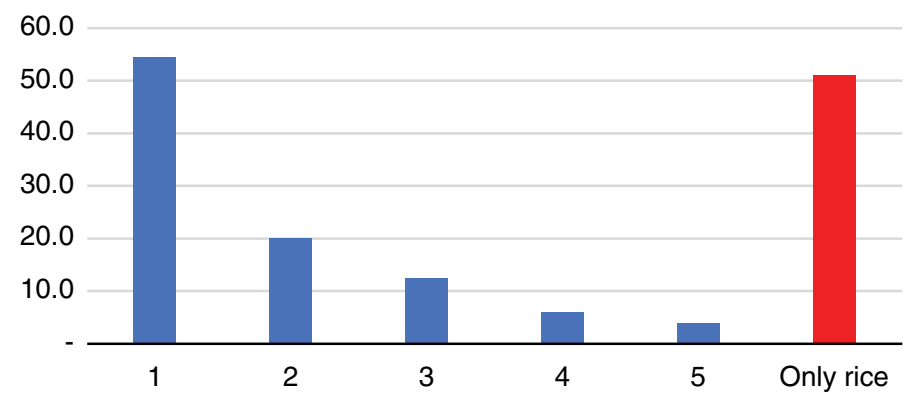

Fig. 15.1. Number of crops grown by farmers in Bangladesh (BIHS, 2012). 


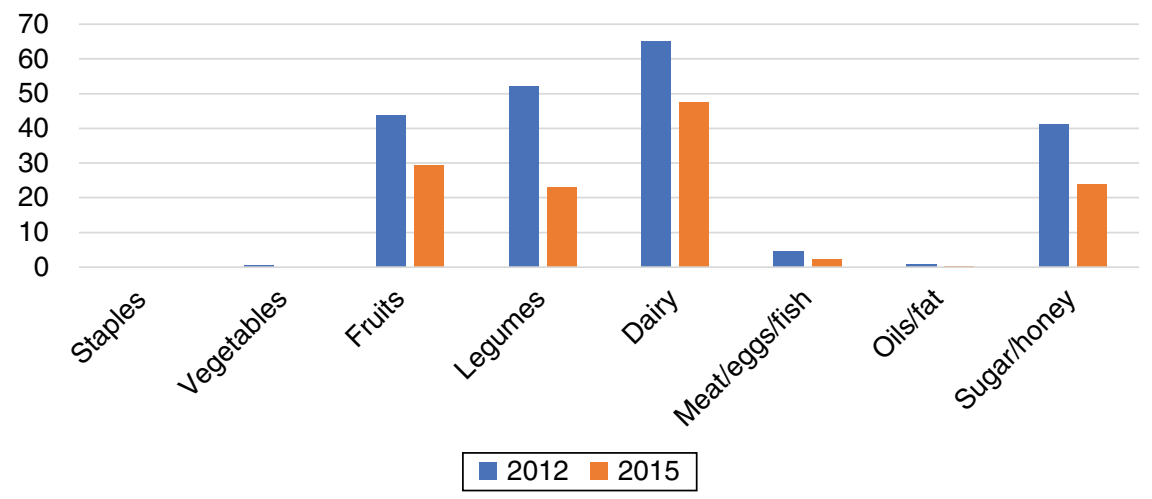

Fig. 15.2. Proportion of people who have not consumed specific food groups in past 7 days from 2012 to 2015 (BIHS, 2012, 2015; Ahmed, 2013).

(with iron and zinc) in the sense that the entire population eats it. Zinc-enriched rice can fight child mortality and stunting, namely by reducing diarrhea and pneumonia.

Recent agricultural research initiatives by HarvestPlus and the Bangladesh Rice Research Institute (BRRI) have made significant headway in research on biofortification. Bangladesh is the first country to develop a rice variety biologically fortified with zinc. Biofortified crops such as high-zinc rice and orange-fleshed sweet potato (OFSP) in Bangladesh have been efficacious in reducing zinc and vitamin A deficiencies. Up to 2016, HarvestPlus had reached nearly half a million farm households with approximately $908 \mathrm{t}$ of seed consisting of four zinc rice varieties in 62 out of 64 districts (HarvestPlus, 2017). These varieties provide up to $60 \%$ of daily zinc needs, along with iron and vitamin A. By 2015, HarvestPlus had reached 160,000 households in Bangladesh with zinc rice and aimed to reach 1.4 million households by 2018 (HarvestPlus, 2017). Biofortified crops are one way in which agriculture is transforming to enhance nutrition outcomes in a rapidly growing population.

Another option is to diversify agriculture by way of utilizing contract farming, which can protect farmers from the price risks of producing other nutrient-dense crops. Under contract farming, the farmer provides agreed quantities of an agricultural product to an agribusiness firm, based on the quality standards and delivery requirements of the firm, usually at a price negotiated and established in advance. Agribusiness firms may also agree to support the farmers through input supply, credit, extension advice, and transporting produce to their premises (Eaton and Shepherd, 2001).

Despite its potential, very few contract farming models have been successfully adopted in Bangladesh. Notable exceptions include tobacco, with support from multinational companies like British American Tobacco; BRAC's crop and non-crop agricultural activities, which connect local producers with BRAC retailers around the country; and the poultry firm Aftab Bahumukhi Farm Limited (ABFL), which provides chicks, feed, veterinary supplies, management services, and transportation to producers in Kishoreganj District (Begum, 2005; Barket et al., 2008).

Strategies that balance the intensification of rice production and agricultural diversification should be prioritized, which may help meet the caloric and nutritional demands of the population, as well as improve farmers' incomes by cultivating more profitable, yet risky crops. Addressing the market efficiency issues is likely to be an effective means of reducing the risks associated with adoption of high-value agricultural production. Carefully designed research is needed to reveal the constraints to agricultural diversity and to formulate appropriate policies to remove them.

\section{Trends in Non-crop Agricultural Production}

Despite the centrality of rice to Bangladesh's agriculture sector, other subsectors of agricultural production have nevertheless been thriving. The growing dynamism of the livestock and 
fisheries subsectors in Bangladesh has great potential to advance food availability, nutrition, and income. While agricultural research often emphasizes crop production, recent studies show that nutritional status is more closely linked to the consumption of animal-based protein sources rich in micronutrients - from livestock and fish, for instance - compared with energy consumption. Therefore, the rise of livestock and fisheries holds promise for both the economic well-being and health of the country.

Aquaculture has experienced rapid growth during the past 30 years, amounting to a 25 -fold increase in farmed fish production (Hernandez et al., 2017). This boom has paved the way for major economic gains. When growth in the agriculture sector was faltering, fisheries was generating an average annual growth rate of $5.5 \%$ from 2007-2008 to 2013-2014 (FRSS, 2017). The fisheries share of value added in agricultural GDP reached 25\% in 2013-2014. In 2014, Bangladesh was the fourth largest aquaculture producer globally, after China, India, and Vietnam (FAO, 2016). This private-led growth primarily benefited thousands of small actors along the fish value chain (Hernandez et al., 2017).

The growth of fisheries has had positive impacts on food consumption and nutrition. Nearly all aquaculture production (94\%) in Bangladesh is consumed domestically (Hernandez et al., 2017). In particular, small indigenous fish are a rich source of animal protein, essential fats, iron, zinc, calcium, and vitamin A. Various studies have found that households in Bangladesh that are involved in aquaculture activities reap immense nutritional benefits and have lower levels of poverty (Murshed-e-Jahan et al., 2010; Murshed-e-Jahan and Pemsi, 2011). Hallman et al. (2003) found that communitybased fishpond technology in poor rural areas of Bangladesh contributed to higher shares of nonfarm income and improved household nutrition. The rise of fisheries in the country has also prompted research on the relative nutrition of farmed fish versus non-farmed fish. Bogard et al. (2017) determined that non-farmed fish are much more effective at closing micronutrient gaps than farmed fish. As fisheries continue to be an important source of income and nutrition for urban and rural households in Bangladesh, research in this area will be critical in advocating for nutrition-sensitive aquaculture policies and programs.
The livestock sector is also an important source of livelihoods for many poor agricultural households in Bangladesh, as well as a source of protein, and vitamins and minerals within diets. Since the poor have relatively little access to land, high-value, labor-intensive enterprises, such as backyard livestock rearing for milk production, provide employment for poor and disadvantaged segments of the population, especially women (Ahmed, 2013). The livestock subsector grew by $3 \%$, and its share in agricultural GDP was $12 \%$ in 2013-2014. Livestock has propelled economic growth and food consumption in Bangladesh, though not without risk. At the household level, for example, evidence suggests that owning livestock may pose sanitation risks. Wardrop et al. (2018) found that households owning livestock and poultry in three countries (including Bangladesh) are at greater risk of contaminated drinking water, which could undercut effective biological utilization of nutrients.

Integrated agriculture programs at the household level, which include livestock and aquaculture, have great potential to improve food consumption, nutrition, and reduce poverty. Further research on designing and implementing nutrition-sensitive policies and programs that support households in safely incorporating fisheries and livestock into their livelihoods portfolio, with minimal risk to nutrition, should be explored.

\section{Drivers of Diverse Diets in Bangladesh}

The discussion above details various factors that drive dietary diversity, including gender and agricultural diversity. The importance of these factors and others is confirmed by recent evidence. Using the 2012 and 2015 BIHS data, Ahmed and Tauseef (2018) estimated the determinants of dietary diversity using two measures: the Food Consumption Score developed by the World Food Programme and household dietary diversity score. They found that diet diversity improves given the following:

- Household male head and spouse have higher levels of education.

- Agricultural diversity increases: household grew higher number of non-rice food crops last year. 
- Women are more empowered (as measured by the Women's Empowerment in Agriculture Index).

- Households have a higher number of milking cows and are engaged in fisheries.

- Rice price increases (households respond to an increase in rice price by partially shifting consumption away from rice to other food items, which results in an increase in dietary diversity).

Relative food prices matter too. The inflationadjusted, real price of rice fell by $53 \%$ in 35 years from 1982 to 2016. The falling price of rice has helped the rural landless and the urban poor, who purchase the rice they consume. The ultra poor cannot purchase enough rice to meet their energy requirements, despite a falling real price of rice. Therefore, the adoption of agricultural technology (that is, high-yielding and stresstolerant seed varieties, fertilizers, and small-scale irrigation) by farmers and institutional innovations that made this price decline possible must be maintained.

However, the real price of several foods that are rich in nutrients demonstrates increasing price trends (Sen et al., 2010). The increase in the real price of non-rice foods probably reflects supply-side constraints, largely related to low level of productivity per unit of land and underdeveloped agricultural value chains for these crops. If policies are not undertaken to increase the supply of non-cereal, nutrient-rich foods (such as pulses, fruits, vegetables and animal-sourced food), prices of these foods will continue to increase in the face of income and population growth. Consequently, the diet quality and nutritional status of the poor may deteriorate further. These observations have important implications for agricultural policy.

\section{The Agriculture, Nutrition, and Gender Linkages (ANGeL) Project: an Example of a Government-led Initiative}

IFPRI's research in Bangladesh shows that agricultural diversity improves household, maternal, and child dietary diversity, and that women's empowerment enhances both dietary diversity and agricultural diversity. Other recent collaborative research such as Alive \& Thrive and the Transfer Modality Research Initiative, the latter undertaken jointly by IFPRI and the World Food Programme, have found that nutrition-oriented behavior change communication training improves household diet quality, child nutrition, and complementary feeding practices (Ahmed et al., 2016; Menon et al., 2016).

Motivated by this evidence, IFPRI designed a pilot project to bridge the gaps among agriculture, nutrition, and gender. 'Orienting Agriculture Towards Improved Nutrition and Women's Empowerment', also referred to as the Agriculture, Nutrition, and Gender Linkages (ANGeL) project, is a 3-year initiative (2015-2018) implemented by Bangladesh's Ministry of Agriculture. It aims to identify actions and investments in agriculture that will help increase farm household income, improve nutrition, and empower women. It was designed to generate definitive evidence on the critical pathways through which underlying drivers of nutrition can be addressed and scaled through nutrition-sensitive agriculture.

IFPRI uses a randomized controlled trial design to evaluate ANGeL's impact on five combinations of three types of interventions for promoting nutrition- and gender-sensitive agriculture through the following modalities:

- Agricultural production: facilitating the production of high-value commodities rich in essential nutrients through the diversification of crops, livestock, fisheries, and so on.

- Nutrition knowledge: conducting highquality training focused on changing behaviors and improving knowledge of nutrition practices, such as cooking and preparation techniques.

- Gender sensitization: undertaking activities to empower women and raise their status while encouraging gender parity.

The ANGeL Project randomly selected 4000 farm households in 16 out of 64 districts in rural Bangladesh, with the majority receiving one of five interventions and a sixth group randomly chosen to not receive any project interventions (control group):

- Option 1: Nutrition trainings conducted by government agriculture extension agents.

- Option 2: Nutrition trainings conducted by trained community women hired by the project. 
- Option 3: Agriculture Production trainings conducted by government agriculture extension agents.

- Option 4: Agriculture Production + Nutrition trainings conducted by government agriculture extension agents.

- Option 5: Agriculture Production + Nutrition + Gender Sensitization trainings conducted by government agriculture extension agents and project-hired facilitators for the gender component.

- Control (875 households).

ANGeL's design draws on a large, nationwide agricultural extension network. In Bangladesh, agricultural extension agents (mostly men) of the Department of Agricultural Extension (DAE) provide services mostly to male farmers to facilitate the adoption of agricultural technologies and modern agricultural production practices; women are rarely reached by DAE agents. ANGeL is deliberately designed to correct this gendered asymmetry in agriculture extension. ANGeL female beneficiaries receive agricultural production training alongside men, which enables them to participate in sole or joint decision-making on agricultural production and marketing (for example, what inputs to buy, crops to grow, what livestock to raise, what and how much produce to sell). On the other hand, men receive key messages on nutrition, since they are the primary buyers of food in rural Bangladesh (women having limited mobility due to religious and social norms of segregation).

ANGeL's initial quantitative impact results support strengthening the agriculture-nutritiongender nexus (Ahmed et al., 2018). Both men and women benefited from agriculture trainings, yet women learned more from the same trainings. Crop diversity increased substantially in homestead gardens, largely due to ANGeL's emphasis on homestead food production for nutritious crops. Farmers also adopted improved production practices on homestead gardens. In particular, women emerged as key contributors towards diversifying home gardens and exhibited nearly double the rates of adoption of vegetable production compared with men across all interventions with agriculture trainings. The initial analysis also consistently found that women were more likely to apply knowledge gained from agriculture production trainings to adopt various types of improved agriculture production practices, such as pest and disease control, seed production and care, and use of fertilizer. Similarly, improvements in nutrition knowledge were far greater for women and when trainings were combined. These improvements in knowledge had impacts on nutrition outcomes, with increases in household diet quality and child dietary diversity over the project period. The strongest improvements in empowerment, as measured by the abbreviated Women's Empowerment in Agriculture Index, were shown when agriculture, nutrition, and gender sensitization trainings were combined (Ahmed et al., 2018). ANGeL's household approach empowered women and men in unique ways: while women became more empowered in asset ownership and income decisions (under option 5), men became more empowered in production and income decisions in select interventions (men's production and income decisions had statistically significant improvements under two interventions: option 2: nutrition BCC trainings delivered by government agriculture extension agents; and option 5: agriculture production, nutrition BCC, and gender sensitization trainings). Attitudes related to gender of both women and men also improved, with more women recognizing that they make important contributions to their communities.

ANGeL is the first ministry-led initiative that uses a rigorous impact evaluation to develop an evidence base to design and implement a national program. ANGeL's findings support the value of improving women's access to agricultural extension, and building the capacity of government agricultural extension agents to motivate behavior change for homestead food production and nutrition. Encouragingly, the government of Bangladesh plans to use the research-based evidence to scale up the most effective interventions all over the country.

\section{Policy Conclusions}

Agricultural growth is key to poverty reduction. Bangladesh's recent slowdown in agricultural growth, mainly due to decreased growth in rice production, needs to be addressed. Rice production must not be de-emphasized. Rather, rice cultivation should be intensified through investment research to increase productivity. 
This will mean developing new technologies and innovations through research to address production problems in flood, drought, and salinity-induced stress conditions. Intensification of rice cultivation has the potential of releasing land for non-rice crop cultivation, without compromising rice production growth. Agricultural technologies must be disseminated to farmers through effective extension systems.

At the same time, the growth in production of non-rice crop and non-crop agricultural commodities must be augmented to improve the dietary diversity of the Bangladeshi population. The historical growth in rice production has not been matched by increased production (and consumption) of vegetables, fruits, milk, eggs and meat, adversely impacting diet quality. Reorienting agriculture for ensuring nutrition can be accomplished through various policy actions.

First, year-to-year price fluctuations are much larger for non-rice crops than for rice, indicating relatively high levels of market-induced risks for production of non-rice crops. Developing value chains to link producers to food processing industries and food supermarkets can help mitigate these risks. As discussed earlier, contract farming can also play an important role, as can an enabling policy environment for the private sector to develop nutrition-sensitive agricultural value chains. Investments in research can also potentially minimize production risks.
Research can play an important role in increasing the productivity of non-staple crops, thereby reducing the cost of production. In addition to improving the productivity of non-staples, research can focus on developing vegetable varieties that: (i) grow well in off-seasons; (ii) are disease- and pest-resistant; and (iii) have high contents of important micronutrients.

Gender needs to be mainstreamed into all relevant agriculture-nutrition policies and programming, in light of the strong links between women's empowerment and agricultural diversity. Hiring more female agriculture extension agents under the Ministry of Agriculture's DAE, for example, could enhance agriculture extension's reach to smallholder farmers - both men and women. Beyond expanding agriculture extension's reach, nutrition messaging could also be integrated into the agricultural extension curriculum.

Finally, more evidence is needed. The government of Bangladesh has shown remarkable willingness to draw upon research to design its policies and large-scale programs. Countrydriven nutrition-sensitive agricultural interventions like the government-led ANGeL project hold promise for generating context-specific policy lessons. These lessons can be applied to overcome Bangladesh's persistent challenges, and set it on the path toward sustained agricultural growth, poverty reduction, and nutrition security.

\section{References}

Ahmed, A. (2013) Bangladesh Integrated Household Survey (BIHS) 2011-2012. International Food Policy Research Institute, Washington, DC. Datasets available at: http://hdl.handle.net/1902.1/21266 (accessed 19 December 2018).

Ahmed, A.U. and Tauseef, S. (2018) 'Using the BIHS data to support agriculture, nutrition, and social protection policies in Bangladesh' [PowerPoint presentation] Poverty, Health, and Nutrition Division Retreat. Available at: https://www.slideshare.net/ifpri/ifpribangladesh-using-the-bihs-data-to-supportagriculture-nutrition-and-social-protection-policies-in-bangladesh (accessed 23 March 2018).

Ahmed, A.U., Aberman, N.L., Jabbar, M. and Akhtar, N. (2011) Policy Perspectives of the Country Investment Plan for Food and Nutrition Security in Bangladesh. Project Report. International Food Policy Research Institute, Dhaka.

Ahmed, A.U., Quisumbing, A.R., Roy, D. and Roy, S. (2013) Evaluating the Dairy Value Chain Project in Bangladesh: Final Impact Report. Evaluation Report Submitted to CARE Bangladesh. International Food Policy Research Institute, Dhaka.

Ahmed, A.U., Hernandez, R., Akter, A., Hossain, N., Quabili, W. et al. (2015) Agricultural value chains in the feed the future zone of influence in Bangladesh: baseline study. Project Report. International Food Policy Research Institute, Dhaka.

Ahmed, A.U., Hoddinott, J.F., Roy, S., Sraboni, E., Quabili, W.R. and Margolies, A. (2016) Which Kinds of Social Safety Net Transfers Work Best for the Ultra Poor in Bangladesh? Operation and Impacts of the Transfer Modality Research Initiative. Project Report. International Food Policy Research Institute, Dhaka. 
Ahmed, A.U., Haque, M.L., Khandaker, M.A.I., Sufian, F. and Tauseef, S. (2017) Promoting agricultural growth, technology adoption, and crop diversity [PowerPoint presentation]. Eliminating Hunger and Malnutrition: Are Sustainable Solutions in Sight? Available at: https://www.slideshare.net/ifpri/promotingagricultural-growth-technology-adoption-and-crop-diversity-in-bangladesh-akhter-ahmed? qid=1ac03c7b-d75c-4ea6-b031-959abc8b68c1\&v=\&b=\&from_search=6 (accessed 20 March 2018).

Ahmed, A.U., Haque, M.L., Hoddinott, J., Hossain, N., Menon, P. et al. (2018) Results from the agriculture, nutrition, and gender linkages project [PowerPoint presentation] ANGeL Results Dissemination Seminar held in Dhaka, Bangladesh on June 6, 2018.

Arimond, M. and Ruel, M.T. (2004) Dietary diversity is associated with child nutritional status: evidence from 11 Demographic and Health Surveys. Journal of Nutrition 134(10), 2579-2585. doi: 10.1093/jn/134.10.2579.

Arimond, M., Hawkes, C., Ruel, M.T., Sifri, Z., Berti, P.R. et al. (2011) Agricultural interventions and nutrition: lessons from the past and new evidence. In: Thompson, B. and Amoroso, L. (eds) Combating Micronutrient Deficiencies: Food-based Approaches. FAO Rome/CAB International, Wallingford, UK, pp. 41-75. doi: 10.1079/9781845937140.0041.

Barket, A., Majid, M., Mahiyuddin, G., Rahman, M., Munir, A.K.M., Kumar, A. and Khan, M. (2008) Contract Farming in Bangladesh: Political Economy of Tobacco Cultivation and Processing. Human Development Resource Centre, Dhaka. Available at: http://www.hdrcbd.com/admin_panel/images/notice/ 1390212962.01.\%20contract\%20farming\%20in\%20bangladesh_\%20political\%20economy\%20 of\%20tobacco\%20cultivation\%20and\%20processing.pdf (accessed 4 November 2018).

BBS (2017) Statistical Yearbook of Bangladesh 2017. Bangladesh Bureau of Statistics, Statistics Division, Ministry of Planning, Government of the People's Republic of Bangladesh, Dhaka.

Begum, I.A. (2005) An assessment of vertically integrated contract poultry farming: a case study in Bangladesh. International Journal of Poultry Science 4(3), 167-176.

BIHS (2012) Bangladesh Integrated Household Survey 2011-2012. International Food Policy Research Institute (IFPRI), Dhaka. Available at: http://www.ifpri.org/publication/bangladesh-integrated-householdsurvey-bihs-2011-2012 (accessed 19 December 2018).

BIHS (2015) Bangladesh Integrated Household Survey 2015. International Food Policy Research Institute (IFPRI), Dhaka. Available at: http://www.ifpri.org/publication/bangladesh-integrated-household-surveybihs-2015 (accessed 19 December 2018).

Bogard, J.R., Marks, G.C., Mamun, A. and Thilsted, S.H. (2017) Non-farmed fish contribute to greater micronutrient intakes than farmed fish: results from an intra-household survey in rural Bangladesh. Public Health Nutrition 20(4), 702-711. doi: 10.1017/S1368980016002615.

Eaton, C. and Shepherd, A. (2001) Contract Farming: Partnerships for Growth. Agricultural Services Bulletin 145. Food and Agriculture Organization of the United Nations (FAO), Rome.

FAO (2016) The State of World Fisheries and Aquaculture 2016. Contributing to Food Security and Nutrition for All. Food and Agriculture Organization of the United Nations, Rome.

FRSS (2017) Yearbook of Fisheries Statistics of Bangladesh, Vol. 33. Fisheries Resources Survey System, Department of Fisheries, Dhaka. Available at: http://document.bdfish.org/2017/07/yearbook-of-fisheriesstatistics-of-bangladesh-2015-2016-volume-33-april-2017/ (accessed 19 December 2018).

Hallman, K., Lewis, D. and Begum, S. (2003) An Integrated Economic and Social Analysis to Assess the Impact of Vegetable and Fishpond Technologies on Poverty in Rural Bangladesh. International Food Policy Research Institute, Dhaka.

HarvestPlus (2017) Promoting Farmers' Adoption of High Zinc Rice: Harvestplus Experience. Project brief prepared for the 'Developing the Seed Sector: What Role for Policy' seminar held in Dhaka in August 2017. Dhaka, Bangladesh.

Hernandez, R., Belton, B., Reardon, T., Hu, C., Zhang, X. and Ahmed, A.U. (2017) The 'quiet revolution' in the aquaculture value chain in Bangladesh. Aquaculture 493, 456-468. doi: 10.1016/j.aquaculture. 2017.06.006.

Hossain, M., Jimi, N.A. and Islam, M.A. (2016) Does agriculture promote diet diversity? A Bangladesh Study. LANSA Working Paper Series, 2016 (11).

ICDDRB, UNICEF and GAIN (2013) National Micronutrient Survey in Bangladesh in 2011-12. Centre for Nutrition and Food Security, International Centre for Diarrhoeal Disease Research, Bangladesh.

Jones, A.D., Ickes, S.B., Smith, L.E., Mbuya, M.N., Chasekwa, B. et al. (2014) World Health Organization infant and young child feeding indicators and their associations with child anthropometry: a synthesis of recent findings. Maternal and Child Nutrition 10(1), 1-17. doi: 10.1111/mcn.12070.

Malapit, H.J., Kadiyala, S., Quisumbing, A., Cunningham, K. and Tyagi, P. (2013) Women's Empowerment in Agriculture, Production Diversity, and Nutrition: Evidence from Nepal. IFPRI Discussion Paper 01313. International Food Policy Research Institute, Dhaka, Bangladesh. doi: 10.2139/ssrn.2405710. 
Menon, P., Bamezai, A., Subandoro, A., Ayoya, M.A. and Aguayo, V. (2015) Age-appropriate infant and young child feeding practices are associated with child nutrition in India: insights from nationally representative data. Maternal and Child Nutrition 11(1), 73-87.

Menon, P., Nguyen, P.H., Saha, K.K., Khaled, A., Sanghvi, T. et al. (2016) Combining intensive counseling by frontline workers with a nationwide mass media campaign has large differential impacts on complementary feeding practices but not on child growth: results of a cluster-randomized program evaluation in Bangladesh-3. Journal of Nutrition 146(10), 2075-2084. doi: 10.3945/jn.116.232314.

Murshed-e-Jahan, K. and Pemsi, D.E. (2011) The impact of integrated aquaculture - agriculture on smallscale farm sustainability and farmers' livelihoods: Experience from Bangladesh. Agricultural Systems 104, 392-402.

Murshed-e-Jahan, K., Ahmed, M. and Belton, B. (2010) The impacts of aquaculture development on food security: lessons from Bangladesh. Aquaculture Research 41, 481-495.

NIPORT (2015) Bangladesh Demographic and Health Survey 2014. National Institute of Population Research and Training (NIPORT), Mitra and Associates, and ICF International, Dhaka, and Calverton, Maryland.

NNS (2017) National Low Birth Weight Survey 2015. Bangladesh. National Nutrition Services (NNS) of Institute of Public Health Nutrition (IPHN), Dhaka.

Rah, J.H., Akhter, N., Semba, R.D., De Pee, S., Bloem, M.W. et al. (2010) Low dietary diversity is a predictor of child stunting in rural Bangladesh. European Journal of Clinical Nutrition 64(12), 1393. doi: 10.1038/ ejcn.2010.171.

Sen, B., Menon, P., Ahmed, A.U. and Chowdhury, F.P. (2010) Food Utilization and Nutrition Security. Report prepared for the Bangladesh Food Security Investment Forum held in Dhaka, Bangladesh in May 2010. International Food Policy Research Institute, Dhaka.

Sraboni, E., Malapit, H.J., Quisumbing, A.R. and Ahmed, A.U. (2014) Women's empowerment in agriculture: what role for food security in Bangladesh? World Development 61, 11-52. doi: 10.1016/j.worlddev. 2014.03.025.

Wardrop, N.A., Hill, A.G., Dzodzomenyo, M., Aryeetey, G. and Wright, J.A. (2018) Livestock ownership and microbial contamination of drinking-water: evidence from nationally representative household surveys in Ghana, Nepal and Bangladesh. International Journal of Hygiene and Environmental Health 221(1), 33-40. doi: 10.1016/j.ijheh.2017.09.014.

World Bank (2017) Bangladesh continues to reduce poverty but at a slower pace. World Bank Feature Story. Available at: http://www.worldbank.org/en/news/feature/2017/10/24/bangladesh-continues-toreduce-poverty-but-at-slower-pace (accessed 24 October 2017). 